\title{
Mathematical modelling of population dynamics of Baikal omul under commercial catch
}

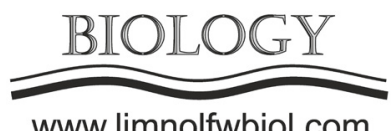

www.limnolfwbiol.com

\author{
Sorokina P.G. ${ }^{1,2}$ \\ ${ }^{1}$ Baikal State University, Lenin Str., 11, Irkutsk, 664003, Russia \\ ${ }^{2}$ Limnological Institute, Siberian Branch of the Russian Academy of Sciences, Ulan-Batorskaya Str., 3, Irkutsk, 664033, Russia
}

\begin{abstract}
Despite the imposed restrictions to conserve the abundance of Baikal omul, the problem of reducing biomass is still urgent. Over the past ten years, the total biomass of Baikal omul has shown a three-fold decrease. The decline of omul stock required to impose another restriction of fishing activity in the water area of Lake Baikal. The order of Ministry of Agriculture of the Russian Federation of 29 August 2017 No. 450 amended the fishing rules for the Baikal fisheries basin, banning the commercial catch of Baikal omul and restricting amateur and sports fishing as well as traditional fishing for indigenous small-numbered peoples, starting from 1st October 2017.
\end{abstract}

Keywords: Baikal omul, fishery, mathematical model, optimal control, numerical simulation.

This work investigates the mathematical model of population dynamics of Baikal omul, taking into account the official catch. We found the optimal strategies for permitted fishing, ensuring the preservation of the omul population at a favorable level as well as regular commercial fishing in the future. We provide an adequate interpretation of the found solutions. The study results can be applied in the development of recommendations for environmental authorities concerning approaches to regulating omul catch.

Mathematical modelling of omul populations is still a relevant issue (Bondarchuk and Perevozkin, 2014; Alekseev et al., 2018; Fedotov et al., 2020; Sukhodolov et al., 2020). This work considers the following model of omul population dynamics:

$$
\dot{x}=a x \frac{K-x}{K}-x u, \quad u \in[0,1], \quad x(0)=x_{0}, \quad t \in[0, T] .
$$

Here, is the amount of biomass of the population at time, $i$ s a fishing effort (rate of fish catch), i.e. control; coefficient of natural growth of population; $r_{e}$ ceiver tank (maximum permissible population size for the studied water area); th biomass of the population at the initial time, . The first term on the right side of the differential equation describes a "natural" population dynamics without external intervention; the second addend characterizes the effect of fishing (or, possibly, other anthropogenic factors) on the population.

One can find the following possible stationary states, in which the population size remains constant.
The first state is trivial ( $x \equiv 0$ ), and the more substantial one is characterized by the formula: $u=a \frac{K-x}{K}$. The latter means that the rate of fish catch ensuring a constant population size is directly proportional to the coefficient of natural growth and the portion of the "free" water area.

We consider several optimal control problems for the above model. One of them is to find the population catch strategy that maximizes the total income of a fishing company in the studied period. The fishing efforts are assumed to be also integrally limited (by resources of the fishing company or permitted quotas).

There are two possible turnpike modes (i.e. the most "favorable" states of the dynamic system). The $x=\frac{K}{2}$ and $u=\frac{a}{2}$ equalities describe one of them, which corresponds to a special case of the above stationary state of the system. Another turnpike mode characterizes complete exhaustion of catch quotas (resources), despite the population state. Due to this fact, it is necessary to take into account certain environmental constraints in the optimization problem. For example, a) prohibition to reduce the population size below the predetermined "minimum" all the time or at control points in time; b) ensuring the required abundance by the end of the studied catch period.

In the future, we will study modifications of optimization problems in the presented model using analytical methods (Dykhta and Sorokin, 2019) as well as computational experiments. 


\section{Acknowledgments}

The present work was supported by RFBR grant No.17-44-388106.

\section{References}

Sukhodolov A.P., Fedotov A.P., Anoshko P.N. et al. 2020. Mathematical modelling in the study of the determinant complex of the illegal catch of aquatic biological resources (omul) in Lake Baikal. Vserossiyskiy Kriminologicheskiy Zhurnal [Russian Journal of Criminology] 14: 76-86. DOI: 10.17150/2500- 4255.2020.14(1).76-86 (in Russian)

Fedotov A.P., Sorokina P.G., Kolesnikova A.V. 2020.
A model for optimizing the catch of renewable resources: the case of the Baikal omul fishery. System Analysis \& Mathematical Modeling 2: 5-14. (in Russian)

Bondarchuk S.S., Perevozkin V.P. 2014. Matematicheskoe modelirovanie $\mathrm{v}$ populyatsionnoy ekologii [Mathematical modelling in population ecology]. Tomsk: Tomskij Gosudarstvennyj Pedagogicheskij Universitet. (in Russian)

Alekseev V.M., Tikhomirov V.M., Fomin S.V. 2018. Optimalnoe upravlenie [Optimal control]. Moscow: Fizmatlit. (in Russian)

Dykhta V., Sorokin S. 2019. Feedback minimum principle for optimal control problems in discrete-time systems and its applications. In: International Conference on Mathematical Optimization Theory and Operations Research, pp. 449-460. DOI: 10.1007/978-3-030-22629-931 